\title{
碱性分子篮作用下甘油与碳酸二甲酯反应制碳酸甘油酯
}

\author{
潘赛勇，郑丽萍，聂仁峰，夏水金金，陈 平，侯昭胤 ${ }^{*}$ \\ 浙江大学化学系催化研究所, 浙江杭州 310028
}

\begin{abstract}
摘要: 报道了温和条件下甘油和碳酸二甲酯在一系列碱性催化剂作用下合成碳酸甘油酯的活性规律和构效关系. 结果表明, 在 所选择的催化剂中, $\mathrm{NaY}$ 分子篮对目标反应具有较高的活性和最高的目的产物选择性; 另外, 甘油和碳酸二甲酯的反应对催化 剂的孔道结构具有特殊的要求, $3 \mathrm{~A}, 4 \mathrm{~A}$ 和 NaZSM-5 等孔径较小 $(<0.6 \mathrm{~nm})$ 的分子篎没有催化活性, 而孔径较大的 $\mathrm{NaY}$ 和 $\mathrm{Na} \beta$ 则表现出较高的催化活性.
\end{abstract}

关键词：碳酸甘油酯；甘油；碳酸二甲酯；分子笁； NaY；酯交换

中图分类号: O643 文献标识码: A

收稿日期: 2012-08-20. 接受日期: 2012-09-03.

*通讯联系人. 电话/传真: (0571)88273283; 电子信箱: zyhou@zju.edu.cn

基金来源: 国家自然科学基金 (21273198,21073159); 浙江省自然科学基金 (LZ12B030001).

本文的英文电子版(国际版)由Elsevier出版社在ScienceDirect上出版(http://www.sciencedirect.com/science/journal/18722067).

\section{Transesterification of Glycerol with Dimethyl Carbonate to Glycerol Carbonate over Na-Based Zeolites}

\author{
PAN Saiyong, ZHENG Liping, NIE Renfeng, XIA Shuixin, CHEN Ping, HOU Zhaoyin* \\ Institute of Catalysis, Department of Chemistry, Zhejiang University, Hangzhou 310028, Zhejiang, China
}

\begin{abstract}
Glycerol carbonate (GC) was synthesized via transesterification of glycerol with dimethyl carbonate under mild conditions over a series of base zeolites. It was found that the $\mathrm{NaY}$ zeolite exhibited a higher selectivity for $\mathrm{GC}(100 \%)$ than heterogeneous bases (such as $\mathrm{CaO}$ and $\mathrm{SrO}$ ) or homogeneous catalysts (such as $\mathrm{NaOH}$ and $\mathrm{K}_{2} \mathrm{CO}_{3}$ ). Further experiments over different base zeolites disclosed that this transesterification reaction depended strongly on catalyst structure. Base zeolites with small pore diameter such as 3A, 4A, and NaZSM-5 were inactive, while $\mathrm{NaY}$ and $\mathrm{Na} \beta$ with larger pore diameter exhibited excellent GC yields under mild conditions.
\end{abstract}

Key words: glycerol carbonate; glycerol; dimethyl carbonate; zeolite; NaY; transesterification

Received 20 August 2012. Accepted 3 December 2012.

*Corresponding author.Tel/Fax: +86-571-88273283; E-mail: zyhou@zju.edu.cn

This work was supported by the National Natural Science Foundation of China $(21273198,21073158)$ and the Natural Science Foundation of Zhejiang Province (LZ12B030001).

English edition available online at Elsevier ScienceDirect (http://www.sciencedirect.com/science/journal/18722067).

With fossil fuels being consumed rapidly and increasing concerns around greenhouse gas emissions, there is much interest in using renewable feedstocks with low carbon dioxide emission as an alternative energy source to petroleum-based materials $[1,2]$. The sustainable production of biodiesel from biomass has not only received much attention from many academic researchers but has also caused many governments to increase their production for economic and environmental reasons [3]. However, the grow- ing production of biodiesel through the transesterification of triglycerides with methanol has generated a large surplus of glycerol as major byproduct (ca. $10 \mathrm{wt} \%$ of manufactured biodiesel). Many biodiesel production factories view crude glycerol as a waste product and dispose of surplus glycerol by incineration.

The catalytic conversion of this biodiesel-derived glycerol into valuable products is a topic of great interest and has received much attention over recent years [4,5]. Glyc- 
erol is an excellent building block which can be converted into various derivatives, for instance, it can be used as a feedstock for the production of propanediols [6], hydroxyacetone $[7,8]$, glycerin ethers $[9,10]$, and glyceride [11]. Recently, the catalytic synthesis of glycerol carbonate (4-hydroxymethyl-1,3-dioxolan-2-one, CAS 931-40-8, abbreviated as GC) from biodiesel-based glycerol has attracted much attention.

$\mathrm{GC}$ is a rather new compound with promising high potential in the chemical industry because of its unique properties (such as biodegradability, low toxicity, high boiling point, low flammability, and moisturizing ability). GC can be used as a component in gas separation membranes, polyurethane foams, coatings, paints, and detergents, and can also be used as a green solvent in the cosmetics industry $[12,13]$. At the same time, GC is an intermediate in the synthesis of a series of chemicals, such as glycidol which is a precursor for the production of a number of polymers. More recently, it was reported that GC and its derivatives can be used as electrolytes in lithium ion batteries instead of ethylene and propylene carbonates [14].

Several syntheses routes of GC from glycerol have been proposed, such as the phosgenation between glycerol and phosgene (reaction (1), Scheme 1) [15], the direct carbonylation of glycerol with carbon dioxide (reaction (2)) [16-18], the glycerolysis of urea (reaction (3)) [19-22], and the oxidative carbonylation of glycerol with a gaseous mixture of carbon monoxide and oxygen over metallic catalysts (reaction (4)) [23,24]. However, some of these methods are problematic. For example, the starting materials are toxic and corrosive (reaction (1)), the direct reaction between glycerol and carbon dioxide must be performed at high pressure, catalyzed by Sn-base complexes and the GC yield is relatively low. The glycerolysis of urea is carried out under vacuum to shift the equilibrium to GC production by continuously removing ammonia (reaction (3)). CO is inflammable and the process is dangerous in the oxidative carbonylation of glycerol with a gaseous mixture of carbon monoxide and oxygen over metallic catalysts (reaction (4)).

Among these proposed routes for GC production from glycerol, one convenient method that should be emphasized is the transesterification between glycerol and organic carbonates (such as dimethyl carbonate, diethyl carbonate, and ethylene carbonate (reactions (5) and (6), Scheme 1) [25-30]. This transesterification reaction could be performed under mild conditions (323-343 K) with various catalysts such as the homogeneous catalyst $\mathrm{K}_{2} \mathrm{CO}_{3}$ [31], the enzymatic catalyst Novozym 435 (a Candida antarctica lipase) [32], and the ionic liquid catalyst imidazolium-2-carboxylates [33]. However, problems associated with these catalysts, such as liquid pollution and separation issues, have hindered their application at large scale. From the viewpoint of green and sustainable chemistry, it is of great importance to find a suitable heterogeneous catalyst to replace the homogeneous ones.

Over the past five years, several heterogeneous catalytic systems have been reported for use in the transesterification reaction between glycerol and dimethyl carbonate (DMC) to GC. Ochoa-Gomez et al. [34] found that $\mathrm{CaO}$ is highly active for this reaction, but the $\mathrm{CaO}$ catalyst is deactivated quickly because of the leaching of $\mathrm{Ca}$ ions. Simanjuntak et al. [35] disclosed that $\mathrm{CaO}$ would dissolve in the glycerol and $\mathrm{DMC}$ reaction mixture, and homogenous $\mathrm{Ca}\left(\mathrm{C}_{3} \mathrm{H}_{7} \mathrm{O}_{3}\right)\left(\mathrm{OCO}_{2} \mathrm{CH}_{3}\right)$ that is formed in situ would in-

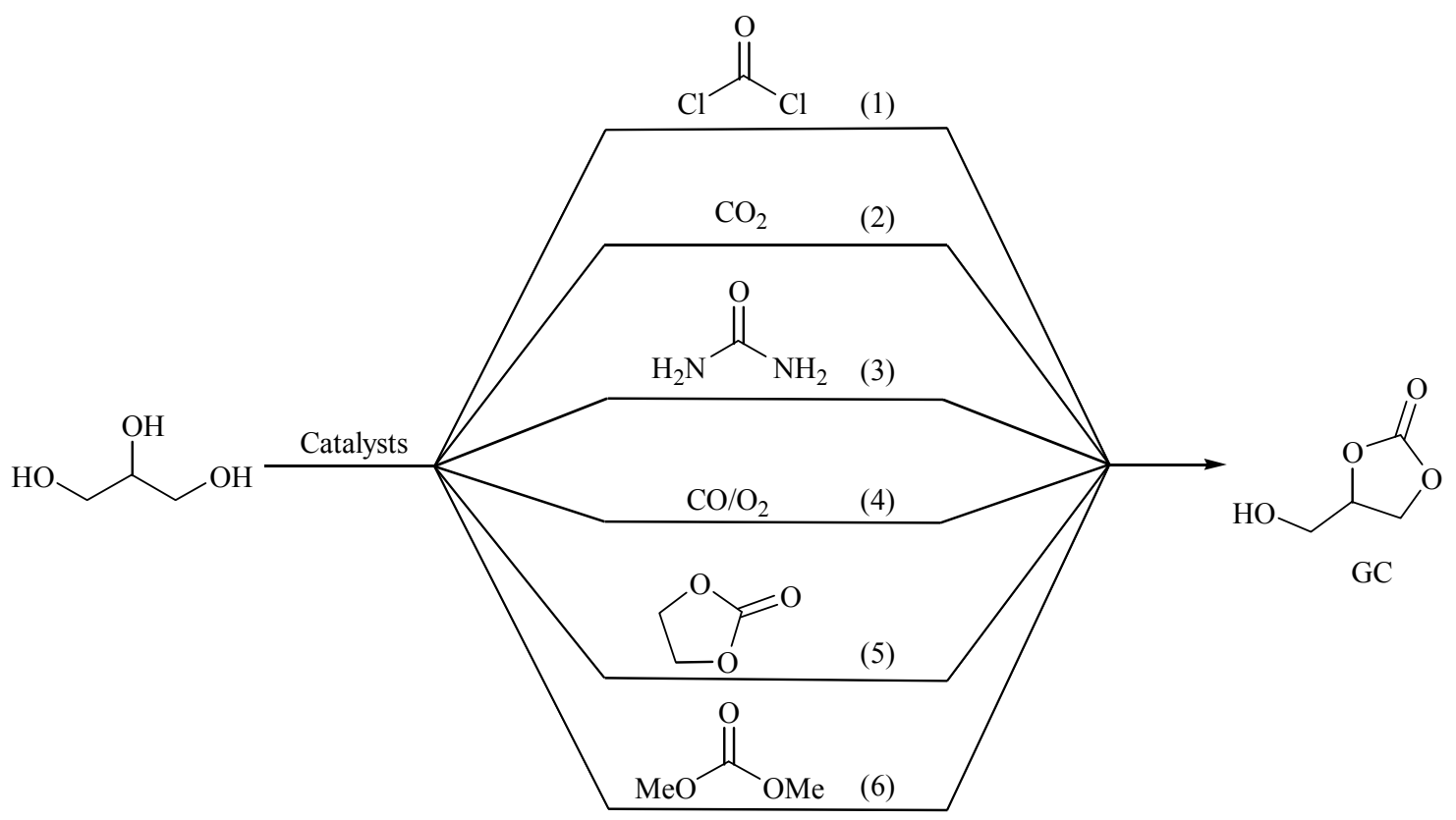

Scheme 1. Synthesis of glycerol carbonate (GC) via different routes. 
crease the formation of GC. Recently, it has been reported that $\mathrm{Mg} / \mathrm{Al}$ hydrotalcites also exhibited good activity for the transesterification reaction between glycerol and DMC, but this reaction should be performed in $\mathrm{N}, \mathrm{N}$-dimethylformamide (DMF) solvent [36,37].

In this work, the transesterification reaction between glycerol and DMC was performed over a series of base zeolites and compared with solid bases (such as $\mathrm{MgO}, \mathrm{CaO}$, $\mathrm{SrO}$, and hydrotalcite) and homogeneous bases (such as $\mathrm{NaOH}$ and $\mathrm{K}_{2} \mathrm{CO}_{3}$ ). The catalytic activity of these base zeolites associated with their structure are discussed.

\section{Experimental}

\subsection{Catalyst preparation}

Commercial $\mathrm{MgO}, \mathrm{CaO}$, and $\mathrm{SrO}$ (AR grade, Sinopharm Chemical Reagent Co., Ltd, China) were calcined at $1173 \mathrm{~K}$ for $8 \mathrm{~h}$ before used. Commercial $\mathrm{K}_{2} \mathrm{CO}_{3}, \mathrm{NaOH}, \mathrm{DMC}$, and glycerol (AR grade, Aldrich, Shanghai Branch, China) were used without further treatment. Mg-Al hydrotalcites (HT, $\mathrm{Mg} / \mathrm{Al}=3$ ) were synthesized by a conventional coprecipitation method as described in previous work [38,39]. The obtained solid was dried at $383 \mathrm{~K}$ in an oven overnight. $\mathrm{NaA}$ zeolites were purchased from Sinopharm Chemical Reagent Co., Ltd, China. NaZSM-5 (Si/Al ratio of 25.0), $\mathrm{Na} \beta$ ( $\mathrm{Si} / \mathrm{Al}$ ratio of 24.6$)$, and $\mathrm{NaY}(\mathrm{Si} / \mathrm{Al}$ ratio of 2.4$)$ zeolite powders were purchased from Nankai University Catalyst Co. The solid zeolite catalysts were dried at $383 \mathrm{~K}$ overnight and calcined at $773 \mathrm{~K}$ for $4 \mathrm{~h}$ before use.

\subsection{Catalytic reactions}

A controlled amount of DMC, methanol, and glycerol were mixed in a $100 \mathrm{ml}$ round bottom three-neck jacketed glass reactor fitted with magnetic stirrer, reflux condenser, sampling device, and thermometer. The mixture was heated with stirring (1200 r/min) to the desired temperature and the catalyst was subsequently added to start the reaction. After reaction, the solid catalyst was removed by centrifugation and the liquid mixture was analyzed using an FID gas chromatograph (Shimadzu, $14 \mathrm{~B}$ ) equipped with $30 \mathrm{~m}$ capillary column (DB-WAX 52 CB, USA). All products detected in the mixture were verified by a GC-MS system (Agilent 6890 ) and quantified using an internal calibration method.

\section{Results and discussion}

\subsection{Catalyst screening}

A series of homogeneous and heterogeneous bases were tested in the transesterification reaction between glycerol
Table 1 Synthesis of GC from glycerol and DMC over different base catalysts

\begin{tabular}{lcccc}
\hline Catalyst & $\begin{array}{c}\text { Base strength } \\
H_{0}{ }^{[38-42]}\end{array}$ & $\begin{array}{c}\text { Glycerol } \\
\text { conversion (\%) }\end{array}$ & $\begin{array}{c}\text { Glycidol } \\
\text { selectivity (\%) }\end{array}$ & $\begin{array}{c}\text { GC selectivity } \\
(\%)\end{array}$ \\
\hline$-^{\mathrm{a}}$ & - & 0 & - & - \\
$\mathrm{NaOH}^{\mathrm{b}}$ & $13-15$ & 77 & 77 & 23 \\
$\mathrm{~K}_{2} \mathrm{CO}_{3}$ & 15.0 & 62 & 49 & 51 \\
$\mathrm{MgO}$ & 15.0 & 21 & 0 & 100 \\
$\mathrm{CaO}$ & 26.5 & 53 & 25 & 75 \\
$\mathrm{SrO}$ & 26.5 & 61 & 28 & 72 \\
$\mathrm{HT}$ & $13.7-16.5$ & 30 & 0 & 100 \\
$\mathrm{NaY}$ & 9.3 & 54 & 0 & 100 \\
\hline
\end{tabular}

Reaction conditions: glycerol $54.3 \mathrm{mmol}$, DMC $162.9 \mathrm{mmol}, \mathrm{CH}_{3} \mathrm{OH}$ $10 \mathrm{ml}$, catalyst $0.5 \mathrm{~g}, 343 \mathrm{~K}, 2$ h. ${ }^{\mathrm{a} C a t a l y s t-f r e e} \cdot{ }^{\mathrm{b}}$ Catalyst $0.2 \mathrm{~g}$.

and DMC at $343 \mathrm{~K}$ for $2 \mathrm{~h}$ with results summarized in Table 1. It was confirmed that the transesterification reaction cannot proceed without catalysts. Similar results reported by Takagaki et al. [37] also indicated that this reaction must be catalyzed by a base. The conversion of glycerol over $\mathrm{NaOH}$ and $\mathrm{K}_{2} \mathrm{CO}_{3}$ reached $77 \%$ and $62 \%$, respectively. However, the selectivity for GC in these homogeneous base-catalyzed mixtures was relatively low and a large amount of glycidol (derived from GC decomposition) was formed. These results are similar to those published previously [34]. On the solid base surface, the detected conversion of glycerol decreased in the order of $\mathrm{SrO}, \mathrm{CaO}, \mathrm{NaY}, \mathrm{HT}$, and $\mathrm{MgO}$. However, glycidol formed in $\mathrm{CaO}$ and $\mathrm{SrO}$ catalyzed solutions, which might be attributed to the strong basicity of $\mathrm{CaO}$ and $\mathrm{SrO}$, and/or the partial solubility of $\mathrm{CaO}$ [35] and $\mathrm{SrO}$ in the reaction mixture $[42,43]$. Among these solid bases, the excellent performance of $\mathrm{NaY}$ should be emphasized as only GC formed even at higher glycerol conversion.

Figure 1(a) shows the transesterification kinetics for the reaction between glycerol and DMC over $\mathrm{NaY}$ at $343 \mathrm{~K}$ in methanol. The conversion of glycerol increased rapidly over the first $4 \mathrm{~h}$ and then changed slightly over the following $4 \mathrm{~h}$ at $343 \mathrm{~K}$. The selectivity for GC remained higher than $99 \%$. Figure 1(b) shows the transesterification kinetics of the reaction between glycerol and DMC over $\mathrm{SrO}$ at $343 \mathrm{~K}$ in methanol. It was found that the selectivity for GC decreased gradually with increasing conversion of glycerol. These results indicate that the transesterification reaction between glycerol and DMC performed in base catalyzed solution, and the detected conversion of glycerol increased with the basic catalyst strength. Strong bases (such as homogeneous $\mathrm{NaOH}, \mathrm{K}_{2} \mathrm{CO}_{3}$, and heterogeneous $\mathrm{CaO}, \mathrm{SrO}$ ) catalyzed the formation of byproducts because $\mathrm{GC}$ decomposed easily in these homogeneous base solutions [19,26]. Those heterogeneous bases with suitable base strength (such as $\mathrm{NaY}$ and HT) exhibited obvious advantages for excellent selectivity 


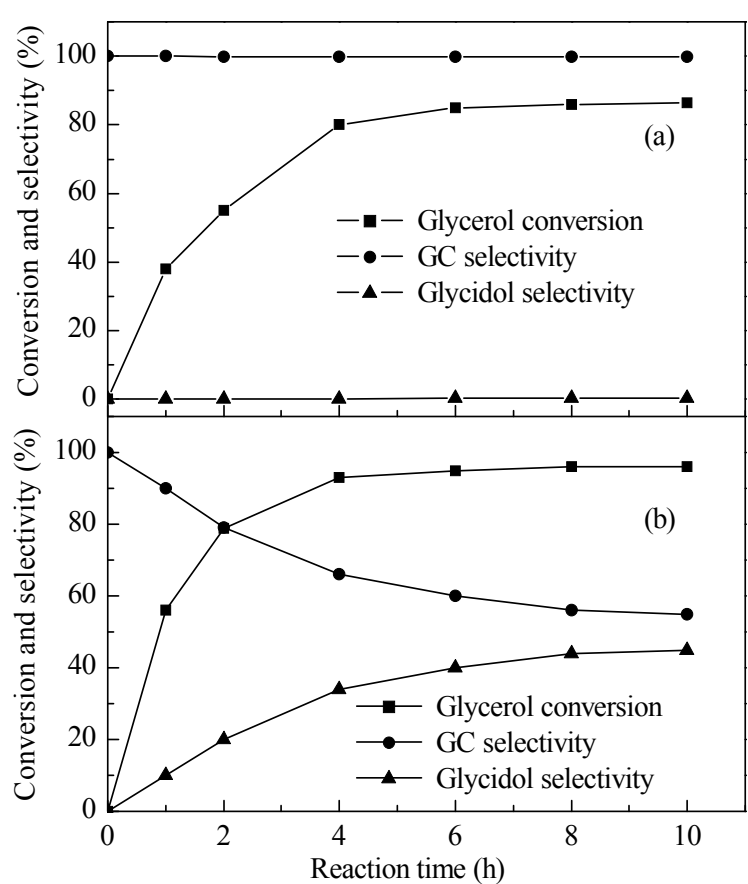

Fig. 1. Transesterification kinetics for reaction of DMC and glycerol over $\mathrm{NaY}$ (a) and SrO (b). Reaction conditions: glycerol $54.3 \mathrm{mmol}$, DMC $162.9 \mathrm{mmol}, \mathrm{CH}_{3} \mathrm{OH} 10 \mathrm{ml}$, catalyst $0.5 \mathrm{~g}, 343 \mathrm{~K}$.

for $\mathrm{GC}$ and ease in separation with $\mathrm{NaY}$ exhibiting the best performance for this reaction.

On the basis of the results summarized in Table 1, it can be inferred that the catalytic transesterification of glycerol with DMC would proceed according to the following steps $[19,26]$. Glycerol is first activated in the base solution to a glycerol anion $[43,44]$, which reacts with DMC to a hydroxyl alkyl carbonate. This hydroxyl alkyl carbonate transforms quickly to GC after the removal of another alcohol. Finally, a byproduct (glycidol) is formed via the decomposition of GC over stronger base sites. The reaction mechanism is summarized in Scheme 2.

\subsection{Transesterification reaction over various zeolites}

Table 2 summarizes the activity of different base zeolites for the transesterification reaction between glycerol and DMC. Surprisingly, 3A, 4A, and NaZSM-5 zeolites were inactive for this reaction. In contrast, $\mathrm{Na} \beta$ and $\mathrm{NaY}$ were

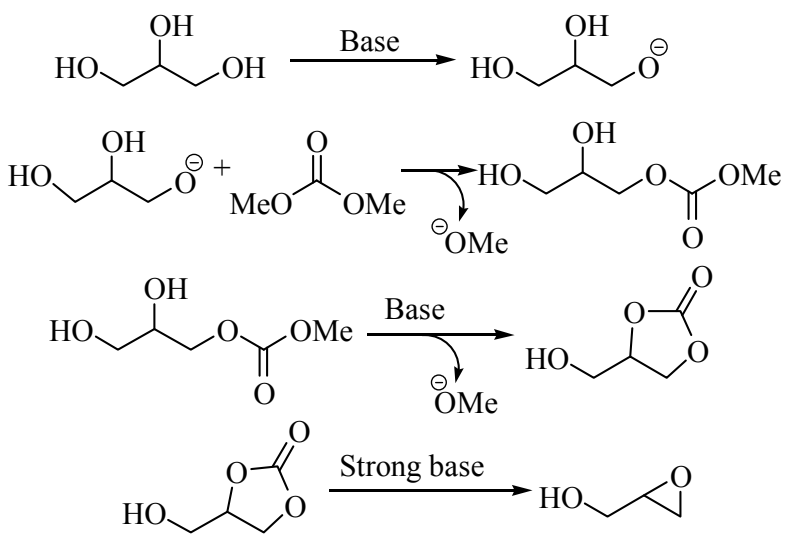

Scheme 2. Synthesis of GC from glycerol and DMC over base catalysts.

able to convert $37 \%$ and $80 \%$ of the glycerol, respectively, at $343 \mathrm{~K}$ and $4 \mathrm{~h}$. At first, these results were postulated to the activity of these catalysts being proportioned to the number of basic sites in the catalysts, but this hypothesis cannot explain the obvious difference between NaZSM-5 and $\mathrm{Na} \beta$ because they have a similar number of basic sites $(0.63-0.64 \mathrm{mmol} / \mathrm{g})$. Apart from the basic sites in catalysts, the pore structure of these zeolites would play a critical role in this reaction. Those zeolites with small pore diameter (such as 3A, 4A, and NaZSM-5 that contain 8- or 10 -numbered ring-structured pore channels) exhibited poor activity. $\mathrm{Na} \beta$ and $\mathrm{NaY}$ contain a 12-numbered ring-structured pore channel and were more active for this reaction. The lower activity of $\mathrm{Na} \beta$ than $\mathrm{NaY}$ could be attributed to the fact that the amount of basic sites in $\mathrm{Na} \beta$ $(0.64 \mathrm{mmol} / \mathrm{g})$ is lower than that of $\mathrm{NaY}(4.2 \mathrm{mmol} / \mathrm{g})$.

The molecular geometrical parameters of DMC, glycerol, and GC were calculated using ChemOffice ${ }^{\odot}$ and are summarized in Table 3. On the basis of these parameters and the pore structure of the zeolites tested, the poor activity of $3 \mathrm{~A}$, 4A, and NaZSM-5 are reasonable because GC cannot form in the poor channels of these catalysts. Glycerol (0.47-0.52 $\mathrm{nm}$ in diameter) [45] can move through the pore channels of NaZSM-5, but GC $(0.33 \mathrm{~nm}$ in diameter and $0.65 \mathrm{~nm}$ in length) is larger than that of the NaZSM-5 channel space. NaZSM-5 can therefore not provide an available space for this reaction and GC diffusion is restricted. On the other hand, $\mathrm{NaY}$ with bigger pore channel $(0.74 \mathrm{~nm} \times 0.74 \mathrm{~nm})$

Table 2 Synthesis of GC from glycerol and DMC over various zeolite catalysts

\begin{tabular}{lcccccc}
\hline Catalyst & Molecular formula & Basic site (mmol/g) & Ring & Pore channel (nm) & Glycerol conversion (\%) & GC selectivity (\%) \\
\hline $3 \mathrm{~A}$ & $\mathrm{Na}_{8} \mathrm{~K}_{4}\left[\mathrm{Al}_{12} \mathrm{Si}_{12} \mathrm{O}_{48}\right]_{8}$ & 1.02 & 8 & $0.31 \times 0.35$ & 0 & 0 \\
$4 \mathrm{~A}$ & $\mathrm{Na}_{12}\left[\mathrm{Al}_{12} \mathrm{Si}_{12} \mathrm{O}_{48}\right]_{8}$ & 1.02 & 8 & $0.41 \times 0.41$ & 0 & 0 \\
NaZSM-5 & $\mathrm{Na}_{3.7}\left[\mathrm{Al}_{3.7} \mathrm{Si}_{92.3} \mathrm{O}_{192}\right]$ & 0.63 & 10 & $0.51 \times 0.55,0.53 \times 0.56$ & 0 & 0 \\
$\mathrm{Na} \beta$ & $\mathrm{Na}_{2.5}\left[\mathrm{Al}_{2.5} \mathrm{Si}_{61.5} \mathrm{O}_{128}\right]$ & 0.64 & 12 & $0.66 \times 0.67,0.56 \times 0.56$ & 37 & 80 \\
$\mathrm{NaY}$ & $\mathrm{Na}_{1.88}\left[\mathrm{Al}_{2} \mathrm{Si}_{4.8} \mathrm{O}_{13.5}\right]$ & 4.20 & 12 & $0.74 \times 0.74$ & 100 & 100 \\
\hline
\end{tabular}

Reaction conditions: glycerol $54.3 \mathrm{mmol}$, DMC $162.9 \mathrm{mmol}, \mathrm{CH}_{3} \mathrm{OH} 10 \mathrm{ml}$, catalyst $0.5 \mathrm{~g}, 343 \mathrm{~K}, 4 \mathrm{~h}$. 
Table 3 Geometrical parameters of molecules in transesterification reaction

\begin{tabular}{lcc}
\hline \multirow{2}{*}{ Substance } & \multicolumn{2}{c}{ Geometrical parameter $(\mathrm{nm})$} \\
\cline { 2 - 3 } & Diameter & Length \\
\hline DMC & 0.37 & 0.45 \\
Glycerol & 0.47 & 0.52 \\
GC & 0.33 & 0.65 \\
\hline
\end{tabular}

allows for the entrance and diffusion of both reactants (glycerol and DMC), and desired product (GC). The excellent performance of $\mathrm{NaY}$ could be attributed to its larger pore diameter and higher number of basic active sites.

\subsection{Transesterification of glycerol and DMC in different solvents}

The results from the transesterification of glycerol and DMC over $\mathrm{NaY}$ in different solvents are summarized in Table 4 . The conversion of glycerol was the lowest $(25 \%)$ when the reaction was performed without solvent at $343 \mathrm{~K}$ for $4 \mathrm{~h}$, and the solvent polarity played a crucial role in glycerol conversion and GC selectivity. Dimethyl sulfoxide (DMSO) can improve glycerol conversion slightly to $45 \%$. The conversion of glycerol further increased to $75 \%$ in ethanol solution, but byproducts formed easily, and the selectivity for GC decreased to $80 \%$. The detected conversion of glycerol in DMF is similar to that in methanol, however, the selectivity for glycidol increased to $2 \%$. Methanol is the optimal solvent for this reaction as it shows the highest conversion of glycerol, the highest GC selectivity, lowest price, and ease of GC separation.

Table 4 Transesterification of glycerol with DMC over NaY in various solvents

\begin{tabular}{lcccc}
\hline Solvent & $\begin{array}{c}\text { Glycerol } \\
\text { conversion (\%) }\end{array}$ & $\begin{array}{c}\text { Glycidol } \\
\text { selectivity (\%) }\end{array}$ & $\begin{array}{c}\text { GC selectivity } \\
(\%)\end{array}$ & $\begin{array}{c}\text { Others } \\
(\%)\end{array}$ \\
\hline DMSO & 45 & 2 & 96 & 2 \\
DMF & 80 & 2 & 98 & 0 \\
Ethanol & 75 & 5 & 80 & 15 \\
Methanol & 80 & 1 & 99 & 0 \\
- $^{*}$ & 25 & 0 & 100 & 0 \\
\hline
\end{tabular}

Reaction conditions: glycerol $54.3 \mathrm{mmol}$, DMC $162.9 \mathrm{mmol}$, solvent $10 \mathrm{ml}$, catalyst $0.5 \mathrm{~g}, 343 \mathrm{~K}, 4 \mathrm{~h}$.

*Solvent free.

\subsection{Recycling of $\mathrm{NaY}$}

Figure 2 shows the activity of the recycled $\mathrm{NaY}$ catalyst for the transesterification of glycerol and DMC in methanol solvent. The catalyst was washed with methanol $(5 \mathrm{ml} \times 5)$ and calcined at $773 \mathrm{~K}(1 \mathrm{~h})$ after each recycle. The mass

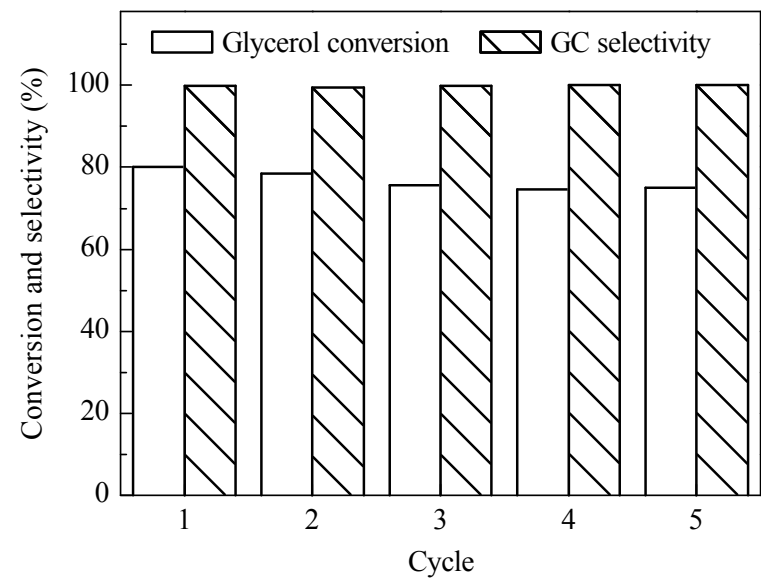

Fig. 2. Recycling of $\mathrm{NaY}$ in transesterification between glycerol and DMC. Reaction conditions: glycerol/NaY=10/1 (mass ratio), DMC $162.9 \mathrm{mmol}, \mathrm{CH}_{3} \mathrm{OH} 10 \mathrm{ml}, 343 \mathrm{~K}, 4 \mathrm{~h}$.

ratio between glycerol and $\mathrm{NaY}$ was controlled at 10 in each cycle. It was found that the conversion of glycerol decreased slightly from $79 \%$ to $78 \%$ in the first three cycles, and then remained stable. The selectivity for GC is higher than $99 \%$ throughout these cycles.

The XRD patterns of the fresh and 5-recycled NaY (Fig. 3) show that the crystalline structure of $\mathrm{NaY}$ zeolite remained stable, which is consistent with its activity (Fig. 2). These results indicate that $\mathrm{NaY}$ zeolite is an efficient catalyst for the transesterification of glycerol and DMC to GC, which is active, selective, and can be recycled.

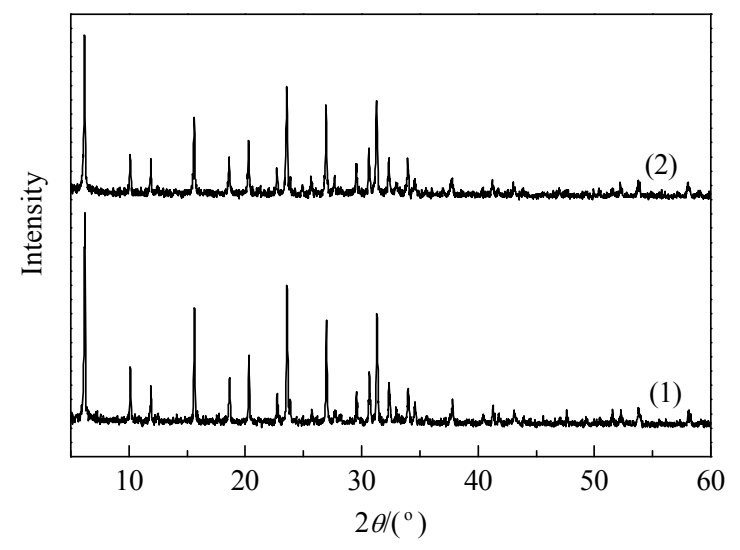

Fig. 3. XRD patterns of fresh (1) and 5-recycled (2) NaY catalyst.

\section{Conclusions}

The transesterification reaction between glycerol and DMC is unfavored thermodynamically and must be catalyzed by a base. $\mathrm{NaOH}$ and $\mathrm{K}_{2} \mathrm{CO}_{3}$ exhibit higher glycerol conversions, but result in the formation of large amounts of byproduct. NaY zeolite exhibited excellent performance for 
this reaction among the tested solid bases as only GC formed even at higher glycerol conversion, and $\mathrm{NaY}$ zeolite could be recycled. The excellent performance of $\mathrm{NaY}$ can be attributed to its larger pore diameter and higher number of base sites.

\section{References}

1 Dodds D R, Gross R A. Science, 2007, 318: 1250

2 Huber G W, Iborra S, Corma A. Chem Rev, 2006, 106: 4044

3 Pagliaro M, Ciriminna R, Kimura H, Rossi M, Della Pina C. Angew Chem, Int Ed, 2007, 46: 4434

4 Zhou C H, Beltramini J N, Fan Y X, Lu G Q. Chem Soc Rev, 2008, 37: 527

5 Sabourin-Provost G, Hallenbeck P C. Bioresource Technol, 2009, 100: 3513

6 Yuan Z L, Wang J H, Wang L, Xie W H, Chen P, Hou Z Y, Zheng X M. Bioresource Technol, 2010, 101: 7088

7 Zope B N, Hibbitts D D, Neurock M, Davis R J. Science, 2010, 330: 74

8 Liang D, Gao J, Sun H, Chen P, Hou Z, Zheng X. Appl Catal $B, 2011,106: 423$

9 Yuan Z L, Xia S X, Chen P, Hou Z Y, Zheng X M. Energy Fuels, 2011, 25: 3186

10 Melero J A, Vicente G, Paniagua M, Morales G, Muñoz P. Bioresource Technol, 2011, 103: 142

11 Corma A, Abd Hamid S B, Iborra S, Velty A. J Catal, 2005, 234: 340

12 Behr A, Eilting J, Irawadi K, Leschinski J, Lindner F. Green Chem, 2008, 10: 13

13 Schaffner B, Schaffner F, Verevkin S P, Borner A. Chem Rev, 2010, 110: 4554

14 Bozell J J, Petersen G R. Green Chem, 2010, 12: 539

15 Shaikh A A G, Sivaram S. Chem Rev, 1996, 96: 951

16 George J, Patel Y, Pillai S M, Munshi P. J Mol Catal A, 2009, 304: 1

17 Vieville C, Yoo J W, Pelet S, Mouloungui Z. Catal Lett, 1998, 56: 245

18 Aresta M, Dibenedetto A, Nocito F, Pastore C. J Mol Catal A, 2006, 257: 149

19 Climent M J, Corma A, De Frutos P, Iborra S, Noy M, Velty A, Concepcion P. J Catal, 2010, 269: 140

20 Aresta M, Dibenedetto A, Nocito F, Ferragina C. J Catal, 2009, 268: 106

21 Wang L G, Ma Y B, Wang Y, Liu S M, Deng Y Q. Catal Commun, 2011, 12: 1458
22 Hammond C, Lopez-Sanchez J A, Ab Rahim M H, Dimitratos N, Jenkins R L, Carley A F, He Q, Kiely C J, Knight D W, Hutchings G J. Dalton Trans, 2011, 40: 3927

23 Hu J L, Li J J, Gu Y L, Guan Z H, Mo W L, Ni Y M, Li T, Li G X. Appl Catal A, 2010, 386: 188

24 Mizuno T, Nakai T, Mihara M. Heteroatom Chem, 2010, 21 541

25 Cho H J, Kwon H M, Tharun J, Park D W. J Ind Eng Chem, 2010, 16: 679

26 Alvarez M G, Segarra A M, Contreras S, Sueiras J E, Medina F, Figueras F. Chem Eng J, 2010, 161: 340

27 Álvarez M G, Plíšková M, Segarra A M, Medina F, Figueras F. Appl Catal B, 2012, 113-114: 212

28 Gordillo A, Lloyd-Jones G C. Chem Eur J, 2012, 18: 2660

29 Zhang X, Wei H. J Nat Gas Chem, 2011, 20: 299

30 范燕平, 王庆印, 杨先贵, 姚洁, 王公应. 催化学报 (Fan Y P, Wang Q Y, Yang X G, Yao J, Wang G Y. Chin J Catal), 2010, 31: 38

31 Rokicki G, Rakoczy P, Parzuchowski P, Sobiecki M. Green Chem, 2005, 7: 529

32 Kim S C, Kim Y H, Lee H, Yoon D Y, Song B K. J Mol Catal $B, 2007,49: 75$

33 Naik P U, Petitjean L, Refes K, Picquet M, Plasseraud L. $A d v$ Synth Catal, 2009, 351: 1753

34 Ochoa-Gomez J R, Gomez-Jimenez-Aberasturi O, MaestroMadurga B, Pesquera-Rodriguez A, Ramirez-Lopez C, Lorenzo-Ibarreta L, Torrecilla-Soria J, Villaran-Velasco M C. Appl Catal A, 2009, 366: 315

35 Simanjuntak F S H, Kim T K, Lee S D, Ahn B S, Kim H S, Lee H. Appl Catal A, 2011, 401: 220

36 Malyaadri M, Jagadeeswaraiah K, Prasad P S S, Lingaiah N. Appl Catal A, 2011, 401: 153

37 Takagaki A, Iwatani K, Nishimura S, Ebitani K. Green Chem, 2010, 12: 578

38 Xia S X, Yuan Z L, Wang L, Chen P, Hou Z Y. Appl Catal A, 2011, 403: 173

39 Yuan Z, Wang L, Wang J, Xia S, Chen P, Hou Z, Zheng X. Appl Catal B, 2011, 101: 431

40 Busca G. Chem Rev, 2010, 110: 2217

41 Gao J, Guo J Z, Liang D, Hou Z Y, Fei J H, Zheng X M. Int J Hydrog Energy, 2008, 33: 5493

42 Zhu J H, Chun Y, Qin Y, Xu Q H. Microporous Mesoporous Mater, 1998, 24: 19

43 Maris E P, Davis R J. J Catal, 2007, 249: 328

44 Lahr D G, Shanks B H. Ind Eng Chem Res, 2003, 42: 5467

45 Levchenko A A, Jain P, Trofymluk O, Yu P, Navrotsky A, Sen S. J Phys Chem B, 2010, 114: 3070 